\title{
Effects of Anthropometric Factors on Foot Size in Normal Preschool Children of Iran
}

\author{
Efectos de los Factores Antropométricos sobre el Tamaño \\ del Pie en Niños Preescolares Normales de Irán
}

Parvin- Dokht Bayat"; Mohammad Mehdi Ahmadi**; Mojtaba Moradi*** \& Ali Ghanbari****

BAYAT, P. D.; AHMADI, M. M.; MORADI, M. \& GHANBARI, A. Effects of anthropometric factors on foot size in normal preschool children of Iran. Int. J. Morphol., 33(3):1141-1145, 2015.

SUMMARY: The growth pattern of children is affected by anthropometric dimensions. This study was aimed to investigate anthropometric factors related to growth of preschool children of a sample population in Iran. This study was performed in year 2011 on 1320 of 4-7 years old preschool children in Arak. To classify, body mass index (BMI), height and weight were recorded. The four contact points (head, back, buttocks, and heels) were maintained against the spine of the stadiometer during measurement. The head was positioned in the Frankfurt plane, and the sliding bar was lowered the crown of the head. Height was measured and recorded by the researchers. A pair of manual calibrated Seca scales was used to measure body mass in kilograms. The participants were least dressed in the uniform. We have classified BMI to four groups as group1, BMI with 10.75-15 and group 2, 3, 4 with 15.1-17 and 17.1-20, 20.1-22.5, respectively. Foot length was recorded as the distance from the posterior aspect of the heel to the most distal aspect of the longest toe. Foot length was measured with subjects standing upright using a foot board, a plastic device with calibrated lineation (in centimeters and millimeters). Analysis showed that sex neither affect on BMI nor foot measurements. The present findings contribute to the understanding of the effect of body mass on the structural development of the pediatric foot and musculoskeletal system. Excessive body mass seems to lead to increased foot length and width.

KEY WORDS: Anthropometry; Body mass index; Iran; Obesity; Sex.

\section{INTRODUCTION}

As an acute public health crisis, obesity in children is related to numerous long-term consequences, including cardiovascular disease, type 2 diabetes, psychosocial problems and also can cause deformity of the musculoskeletal system (Dowling et al. 2005). Several studies have investigated the effects of obesity on foot pressure, structure and function (Cousins et al., 2013; Dowling et al., 2001, 2004; Riddiford-Harland et al., 2000; Gilmour \& Burns, 2001).

As the measurements of foot pressure offers some insight into the biomechanics of the growing foot, some models have been proposed to measure the foot kinematics especially in children (Bosch et al., 2007; Stebbins et al., 2006). In this regards, many studies around the world are conducted to demonstrate the relationships between body mass index (BMI) and the biomechanical characteristics of gate wearing of obese prepubescent children by identifying plantar pressure pattern and also measuring anthropometric parameters of foot. However, there is little data about the influence of obesity on foot structure in the case of prepubescent children of Iran.

The present study aimed at evaluating anthropometric characteristics of the upper and lower limbs and also BMI in the preschool children (4 to 7 years old) of Arak (Central Iran) as a subgroup of population of Iran and demonstrating the relationship between such data and obesity of the subjects.

\section{MATERIAL AND METHOD}

Anthropometric Measurements. This cross-sectional research was carried out in the year 2011 on 1320 of 4-7 year-old preschool children (640 males and 680 females) in

* Department of Anatomy, Arak Medical School, Arak University of Medical sciences, Arak, Iran.

** Student Research Committee, Kermanshah University of Medical Sciences, Kermanshah, Iran.

*** Department of Biology, Islamic Azad University, Hamedan Branch, Hamedan, Iran.

***** Fertility and Infertility Research Center, Kermanshah University of Medical Sciences, Kermanshah, Iran. 
Arak (Central Iran). The research was designed following indications of the ethics committee of Arak Medical Sciences University and was supported by a cooperative research grant (no 92314) from Arak and Kermanshah Medical Sciences Universities. These children were selected by staged clustering method from 37000 preschool children of Arak city. The samples were selected from a unique living region to exclude social class effect. To classify body mass index, height and weight were recorded. Before data collection, participants were asked to remove their shoes and socks. Height was measured with a portable stadiometer. Each of children was asked to stand erect with his or her feet at shoulders level parallel to horizontal plane. The four contact points (head, back, buttocks, and heels) were maintained against the spine of the stadiometer during measurement. The head was positioned in the Frankfurt plane, and the sliding bar was lowered the crown of the head. Height was measured and recorded by the researchers. A pair of manual calibrated Seca scales was used to measure body mass in kilograms. The participants were least dressed in the uniform (Bayat \& Ghanbari, 2009; Bayat et al., 2010). We have classified BMI to four groups as group1, BMI with 10.7515 and groups 2, 3, 4 with 15.1-17 and 17.1-20, 20.1-22.5, respectively.

Foot length was recorded as the distance from the posterior aspect of the heel to the most distal aspect of the longest toe. Foot length was measured with subjects standing upright using a foot board, a plastic device with calibrated lineation (in centimeters and millimeters).

Forefoot width was measured as the widest horizontal distance of the forefoot- from the most medial aspect of the first metatarsal head to the most lateral aspect of the fifth metatarsal head. With subjects standing, forefoot width was measured with a calibrated caliper and values were recorded in centimeters and millimeters. Femoral circumference (FC) was measured in centimeters in standing position with a tape at the largest horizontal circumference around the femur. Mid-upper-arm circumference (MUAC) was measured in centimeters in standing position with a tape at the largest horizontal circumference around the brachium.

Face length was recorded as the distance from the glabella to the most distal aspect of the inferior margin of mandible. Face width was measured as the widest horizontal distance of the face-from the most lateral aspect of the zygomatic bones.

Statistical analysis. Data were presented as Mean \pm SD. Multiple comparisons were calculated by one-way ANOVA. For comparing the two groups, statistical student's t-test was used. Pearson's product-moment correlation coefficients between variables were computed. The significance level chosen was $\mathrm{P}<0.05$.

\section{RESULTS}

The means and standard deviations of the variables were given in Table I. Differences between age groups (4-7 years old) were significant for foot surface, foot width, foot length, but not for Length Index determining the effect of age on size of foot in both sexes (Table II).

Pearson's correlation coefficients were given in Table III. Analysis showed that sex neither affect on BMI nor foot measurements. The details of these data are shown in Figure 1. Table II also shows that the size of foot has positive significant correlations with age, length, weight, femoral circumferences and brachial circumference but with length index has negative significance correlation.

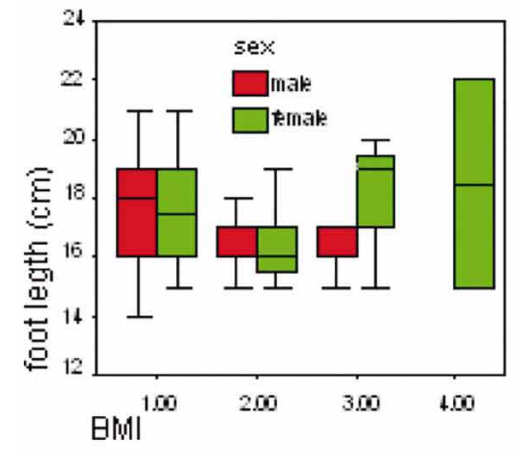

(A)

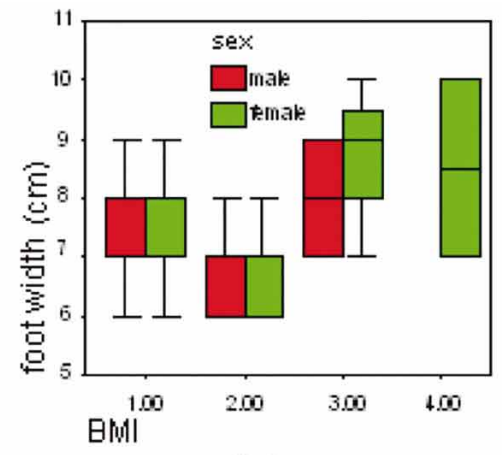

(B)

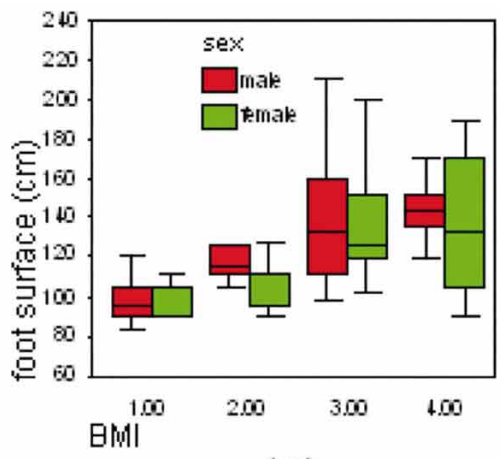

(C)

Fig. 1. Comparison of means of foot-length (A), foot-width (B) and foot surface (C) in female and male preschool children of Arak city (2011). 
Table I. Anthropometric measurements in preschool children of Arak city (2011).

\begin{tabular}{lcccc}
\hline & Minimum & Maximum & Mean & SD \\
\hline Length & 94 & 125 & 108.88 & 7.39 \\
Weight & 13 & 33 & 17.99 & 2.84 \\
Length index & 41.6 & 53.68 & 46.06 & 2.54 \\
Cir. brachium & 15 & 26 & 17.93 & 1.75 \\
Cir. femoral & 22 & 39 & 29.55 & 3.26 \\
Foot length & 14 & 22 & 17.07 & 1.76 \\
Foot width & 6 & 10 & 7.36 & 1.06 \\
Foot surface & 84 & 220 & 127.19 & 30.41 \\
BMI & 10.75 & 22.17 & 17.19 & 3.41 \\
\hline
\end{tabular}

Table II. Comparison of means of foot measurment in four groups BMI in preschool children of Arak city (2011).

\begin{tabular}{lcc}
\hline & Mean Square & $\begin{array}{c}\text { Sig. } \\
\text { (betwe en groups) }\end{array}$ \\
\hline Foot surface & 6884.20 & 0.001 \\
Foot width & 10.76 & 0.001 \\
Foot length & 11.91 & 0.001 \\
Length Index & 15.73 & 0.05 \\
\hline
\end{tabular}

Table III. Pearson's correlation coefficients between anthropometric variables in preschool children of Arak city (2011).

\begin{tabular}{|c|c|c|c|c|c|c|c|c|c|}
\hline & Age & Length & Weight & $\begin{array}{l}\text { Length } \\
\text { index }\end{array}$ & $\begin{array}{c}\text { Cir. } \\
\text { femoral }\end{array}$ & $\begin{array}{c}\text { Cir. } \\
\text { brachium }\end{array}$ & $\begin{array}{c}\text { Foot } \\
\text { lenght }\end{array}$ & $\begin{array}{l}\text { Foot } \\
\text { width }\end{array}$ & $\begin{array}{c}\text { Foot } \\
\text { surface }\end{array}$ \\
\hline BMI & $-0.361 * *$ & $-0.214^{*}$ & $0.535 * *$ & --- & $0.408 * *$ & $0.378^{* *}$ & --- & --- & --- \\
\hline Foot length & $0.557^{* *}$ & $0.690^{* *}$ & $0.520 * *$ & $-0.611 * *$ & $0.281 * *$ & $0.475^{* *}$ & 1 & $0.752 * *$ & $0.908 * *$ \\
\hline Foot width & $0.444 * *$ & $0.363 * *$ & $0.575^{* *}$ & $-0.331 * *$ & $0.365 * *$ & $0.540 * *$ & $0.363 * *$ & 1 & $0.955^{* *}$ \\
\hline Foot surface & $0.475 * *$ & $0.650^{* *}$ & $0.512 * *$ & $0.454 * *$ & $0.345^{* *}$ & $0.550 * *$ & $0.908 * *$ & $0.955^{* *}$ & 1 \\
\hline
\end{tabular}

$* *=$ Correlation is significant at the 0.01 level (2- tailed). * Correlation is significant at the 0.05 level (2- tailed).

\section{DISCUSSION}

A variety of musculoskeletal problems have been associated with excessive body mass in children, including structural foot problems. Excessive body mass affects the discrete anthropometric structure of the peripubescent foot. With the growing concern about childhood obesity, further research is essential to develop a comprehensive understanding of the issues identified and to quantify the findings presented here.

The foot anthropometry results reported for the preschool children (4 to 7 years of age) in the present study are consistent with the previous research of Dowling et al. (2001), who reported larger foot dimensions for obese primary school-aged children ( 7 to 12 years of age) relative to those of their non-obese peers. These findings suggest that overweight/ obese children as young as 3 years of age display foot dimensions that are significantly greater than those of non overweight children.

Our study demonstrated that the development of the foot in preschool-aged children was influenced by 4 factors: age, length, BMI and length index.

Age is the primary predictive factor for development of foot, and the age effective greater on length of foot. Our study demonstrates that the development of the foot in preschool-aged children is not influenced by sex. This difference in result may be that in this study children were younger than Dowling's et al. (2001) study. 
Pfeiffer et al. (2006) showed that 3 variables had a significant relationship to the prevalence of flexible flat foot: age, sex, and weight but in these study no significant difference between female and male.

Morrison et al. (2007) indicated that differences in foot length, forefoot width, and navicular height were presented in children of excessive body mass compared with those of normal body mass. It was observed that children with severe obesity had the longest feet. These findings are consistent with those of Mauch et al. (2008) who reported an increase in foot length and foot width with body mass index. An increase in forefoot width was also observed.

Independent $t$ - tests were calculated to compare mean values in two sex groups of normal BMI children.

The present study also demonstrates that foot measurements is influenced by BMI but is not related to the sex. However, it is difficult to postulate the effect of BMI on foot length and forefoot width. Ligamentous creep could be considered as a potential reason for this issue. The term ligamentous creep refers to stretching and decreased strength in ligaments caused by continuous stresses on them, which in turn causes instability of the forefoot during weightbearing. Numerous reasons for such structural foot changes can be postulated: 1) biomechanical deformity (pes planus), 2) a hormonal cause of excessive mass (eg, increased height seen subjects with excessive body mass), 3 ) an excess of adipose tissue, 4) increased bone formation and subperiosteal expansion resulting from increased plantar forces and pressures experienced during gait, and 5) a combination of these factors.

The present findings contribute to the understanding of the effect of body mass on the structural development of the pediatric foot and musculoskeletal system. Excessive body mass seems to lead to increased foot length and width. It is postulated that biomechanical changes in the behavior of forces and the configuration of the complex joint interactions in the foot may result in disruption to foot alignment and function. The present data could be useful for drawing growth curve of children by measuring body indices for predicting the rate of obesity in the future life.

\section{ACKNOWLEDGEMENT}

This work is supported as a grant (no. 92314) from Kermanshah University of Medical Sciences.

BAYAT, P. D.; AHMADI, M. M.; MORADI, M. \& GHANBARI, A. Efectos de los factores antropométricos sobre el tamaño del pie en niños preescolares normales de Irán. Int. J. Morphol., 33(3):11141-1145, 2015.

RESUMEN: El patrón de crecimiento de los niños se ve afectado por las dimensiones antropométricas. El objetivo fue investigar los factores antropométricos relacionados con el crecimiento de los niños en edad preescolar de una muestra poblacional de Irán. Este estudio se realizó en el año 2011 en 1320 niños, de 4-7 años, de edad preescolar de Arak. Para clasificar el índice de masa corporal (IMC), se registraron la altura y el peso. Los cuatro puntos de contacto (cabeza, espalda, glúteos y talones) se mantuvieron contra la columna del estadiómetro durante la medición. La cabeza fue colocada en el plano de Frankfurt, y la barra de deslizamiento se redujo al nivel de la corona de la cabeza. Los investigadores midieron y registraron la altura. Se utilizaronn par de escalas manuales Seca calibradas para medir la masa corporal en kilogramos. Los participantes fueron vestidos con el uniforme escolar. Se clasificó el IMC en cuatro grupos: grupo 1 entre 10,75-15, grupo 2 entre 15,1-17, grupo 3 entre 17,1-20 y grupo 4 entre 20,1-22,5. La longitud del pie se definió como la distancia existente desde la cara posterior del talón hasta la porción más distal del dedo más largo. La longitud de pie se midió con los sujetos en posición de pie utilizando una tabla de pie, dispositivo de plástico con la alineación calibrada (en centímetros y milímetros). El análisis mostró que el sexo no influye en el índice de masa corporal ni las medidas del pie. Los presentes hallazgos contribuyen a la comprensión de los efectos de la masa corporal en el desarrollo estructural del pie y el sistema músculo-esquelético pediátrico. La masa corporal excesiva parece conducir a un aumento de la longitud y ancho del pie.

PALABRAS CLAVE: Antropometría; Índice de masa corporal; Irán; Obesidad; Sexo.

\section{REFERENCES}

Bayat, P. D. \& Ghanbari, A. The evaluation of craniofacial dimensions in female Arak newborns (central Iran) in comparison with other Iranian racial subgroups. Eur. J. Anat., 13(2):77-82, 2009.
Bayat, P. D.; Ghanbari, A. \& Chehreie, S. Relationship between body mass index and the development of cranium in Arak newborns (central Iran). Ital. J. Anat. Embryol., 115(3):218-22, 2010. 
Bosch, K.; Gerss, J. \& Rosenbaum, D. Preliminary normative values for foot loading parameters of the developing child. Gait Posture, 26(2):238-47, 2007.

Cousins, S. D.; Morrison, S. C. \& Drechsler, W. I. Foot loading patterns in normal weight, overweight and obese children aged 7 to 11 years. J. Foot Ankle Res., 6(1):36, 2013.

Dowling, A. M.; Steele, J. R. \& Baur, L. A. Does obesity influence foot structure and plantar pressure patterns in prepubescent children? Int. J. Obes. Relat. Metab. Disord., 25(6):845-52, 2001.

Dowling, A. M.; Steele, J. R. \& Baur, L. A. What are the effects of obesity in children on plantar pressure distributions? Int. J. Obes. Relat. Metab. Disord., 28(11):1514-9, 2004.

Dowling, A. M.; Steele, J. R. \& Baur, L. A. How Does Obesity and Gender Affect Foot Shape and Structure in Children? Case Western Reserve University Printing Services: Cleveland, OH, USA, 2005.

Gilmour, J. C. \& Burns, Y. The measurement of the medial longitudinal arch in children. Foot Ankle Int., 22(6):4938, 2001.

Mauch, M.; Grau, S.; Krauss, I.; Maiwald, C. \& Horstmann, T. Foot morphology of normal, underweight and overweight children. Int. J. Obes. (Lond), 32(7):1068$75,2008$.

Morrison, S. C.; Durward, B. R.; Watt, G. F. \& Donaldson, M. D. Anthropometric foot structure of peripubescent children with excessive versus normal body mass: a cross-sectional study. J. Am. Podiatr. Med. Assoc., 97(5):366-70, 2007.

Pfeiffer, M.; Kotz, R.; Ledl, T.; Hauser, G. \& Sluga, M. Prevalence of flat foot in preschool-aged children. Pediatrics, 118(2):634-9, 2006.

Riddiford-Harland, D. L.; Steele, J. R. \& Storlein, L. H. Does obesity influence foot structure in prepubescent children? Int. J. Obes. Relat. Metab. Disord., 24(5):541-4, 2000.

Stebbins, J.; Harrington, M.; Thompson, N.; Zavatsky, A. \& Theologis, T. Repeatability of a model for measuring multi-segment foot kinematics in children. Gait Posture, 23(4):401-10, 2006.

\author{
Correspondence to: \\ Ali Ghanbari \\ Fertility and Infertility Research Center \\ Kermanshah University of Medical Sciences \\ Kermanshah \\ IRAN
}

P.O. Box 1568
Tel-Fax: $+98-831-4281563$

Email: aghanbari@kums.ac.ir

Received: 08-04-2014

Accepted: 10-07-2015 